\title{
GAS EXCHANGE RATE MEASUREMENTS IN NATURAL SYSTEMS
}

\section{W S BROECKER, T-H PENG, G MATHIEU, R HESSLEIN, and T TORGERSEN*}

\author{
Lamont-Doherty Geological Observatory and the Department of \\ Geological Sciences of Columbia University \\ Palisades, New York 10964
}

\begin{abstract}
Rates of $\mathrm{CO}_{2}$ exchange across the air-water interface in oceans and lakes measured to date by the $\mathrm{L}$-DGO group are summarized. They range from 3 to 38 moles $/ \mathrm{m}^{2} / \mathrm{yr}$. The possible causes for this range include the differences in salinity, mean wind speed, and $\mathrm{pH}$. Wind tunnel studies comparing fresh water and sea water are required before a satisfactory explanation can be found.
\end{abstract}

One of the long term programs conducted by the geochemistry group at the Lamont-Doherty Geological Observatory has been the development of methods for the measurement of gas exchange rates in natural systems. Our work in this area can be divided into three parts: that devoted to the ocean, that devoted to the closed basin lakes in the western United States, and that devoted to the small fresh-water lakes in the Experimental Lakes Area (ELA) located in western Ontario, Canada.

Our oceanic gas exchange estimates are based on the distributions of natural radiocarbon, bomb-produced radiocarbon and radon. As can be seen in table 1 , the mean $\mathrm{CO}_{2}$ invasion rates calculated by the three methods are in satisfactory agreement. Although the radon method gives a lower result (13-16 moles $/ \mathrm{m}^{2} \mathrm{yr}$ ) than those by the natural and bomb ${ }^{14} \mathrm{C}$ methods (19 and 22 moles $/ \mathrm{m}^{2} \mathrm{yr}$ ), the difference is only slightly greater than the uncertainty of the estimates (Peng and others, 1979).

In calculating the apparent film thicknesses from the piston velocities determined from the distributions of natural and bomb radiocarbon, we have assumed that the reaction rate between $\mathrm{CO}_{2}$ and $\mathrm{OH}^{-}$ion to form $\mathrm{HCO}_{3}-$ ion is too slow to enhance the invasion rate of $\mathrm{CO}_{2}$. As pointed out by Bolin (1960), in the absence of catalysts, this assumption should be valid. Although Berger and Libby (1969) proposed that enzymes leaking from marine organisms might supply the needed catalysts, there has been no subsequent support for this hypothesis. The near agreement between the $\mathrm{CO}_{2}$ and radon based results given allows a limit to be placed on the rate of catalysis in the ocean. It suggests that the enhancement in the invasion rate of $\mathrm{CO}_{2}$ gas by this mechanism is no more than 50 percent.

Pyramid, Walker, and Mono Lakes occupy closed basins. The water they receive from rain and river runoff is lost by evaporation. Broecker and Walton (1959) attempted to use the natural ${ }^{14} \mathrm{C} / \mathrm{C}$ ratio in the dissolved organic carbon of these lakes as a basis for estimates of the $\mathrm{CO}_{2}$ exchange rate. From measurements made over a two-decade-long period (1957 to 1978), we can make independent estimates based on the accumulation of bomb-produced ${ }^{14} \mathrm{C}$ in these lakes. The results are

* Woods Hole Occanographic Institution, Woods Hole, Massachusetts 


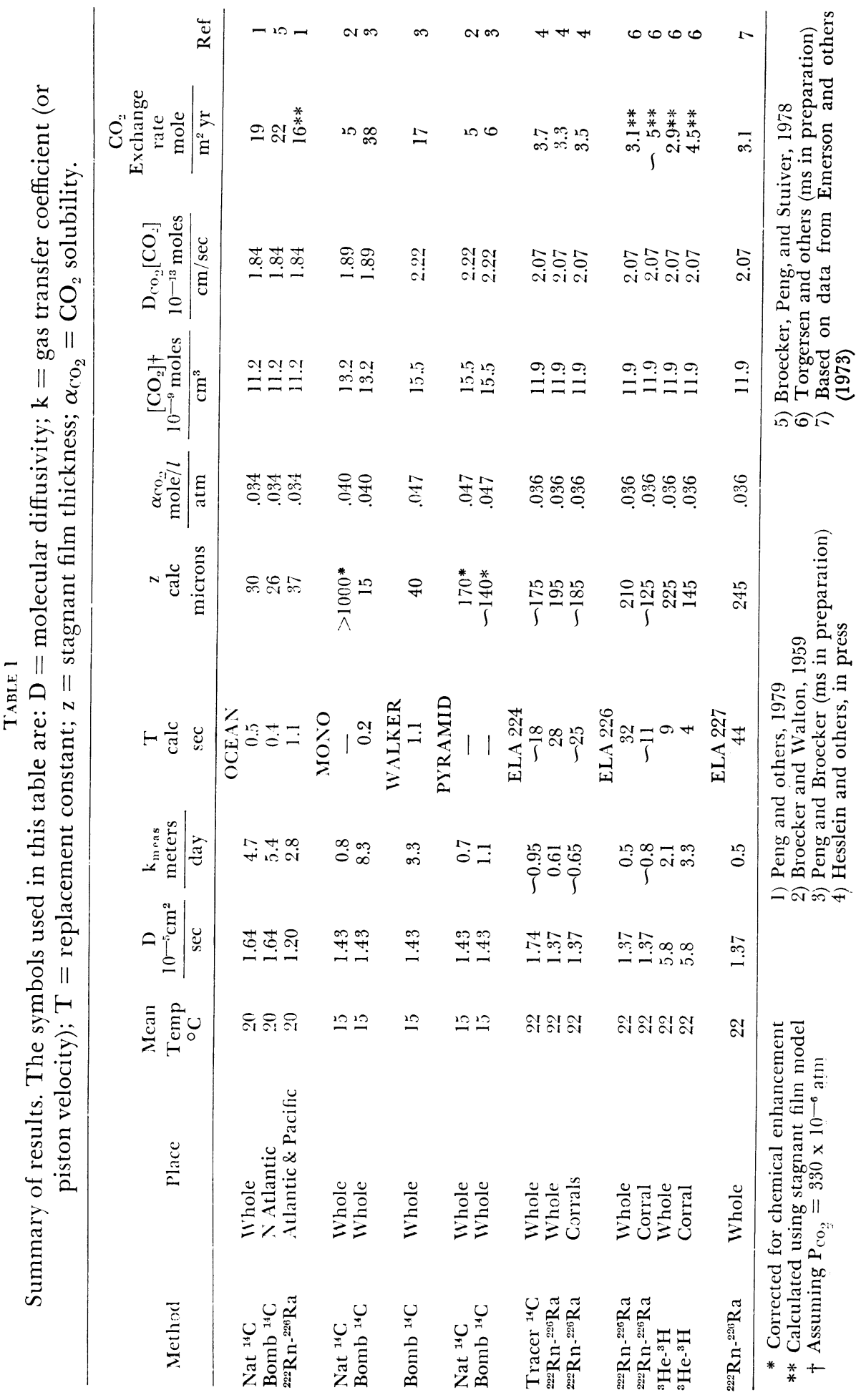


PLATE 1

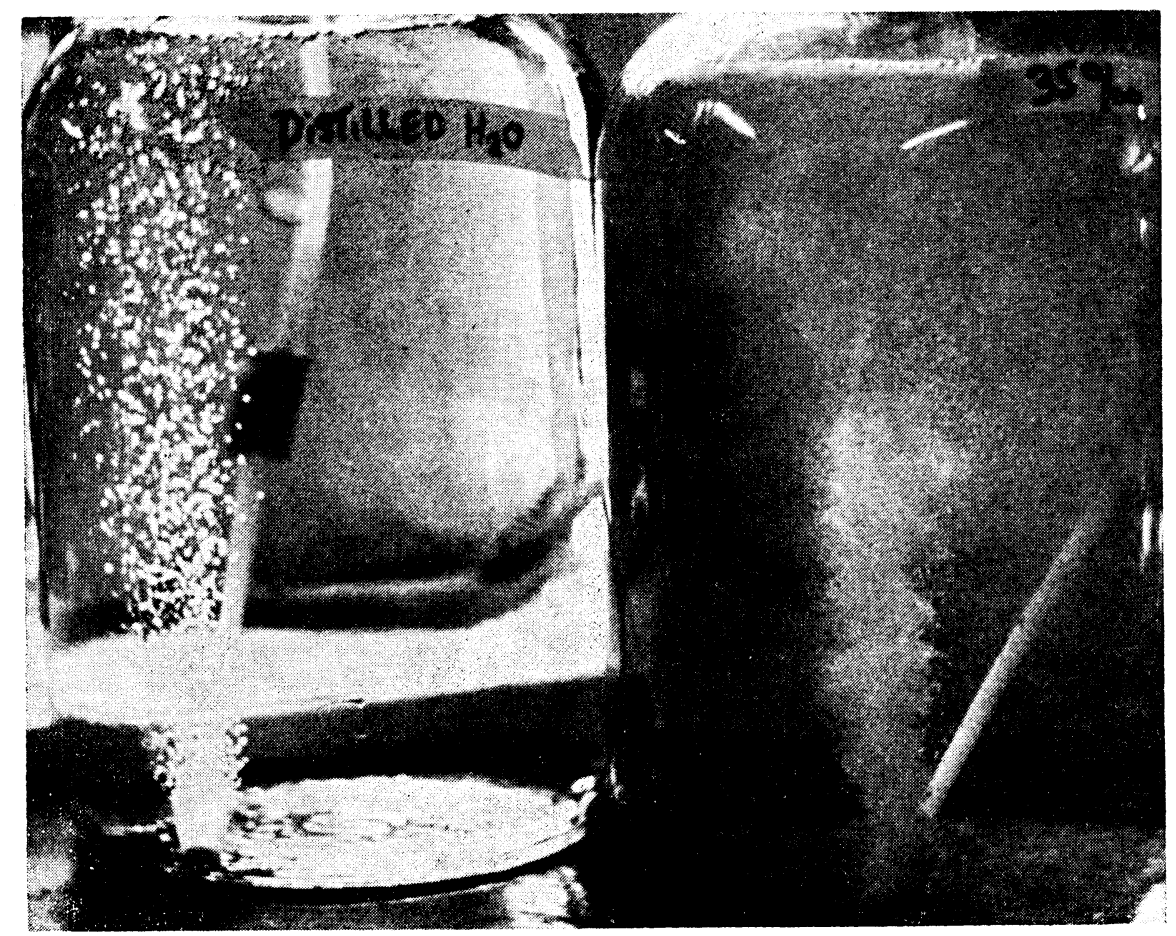

Photograph comparing the bubble size for distilled water and sea water.

summarized in table 1 . Because of its short carbon turnover $(\sim 1$ year $)$ the results for Great Salt Lake lead to ambiguous conclusions and, hence, are not given here.

The largest uncertainty in the estimates, based both on natural and bomb ${ }^{14} \mathrm{C}$, lies in the assumptions made with regard to the input of ${ }^{14} \mathrm{C}$ and of ${ }^{12} \mathrm{C}$ from rivers and springs. Mono Lake currently receives no significant input of river carbon (these waters have been diverted to Los Angeles through an aqueduct). It does, however, receive water from salty springs (hot and cold). The large difference between the result based on the natural ${ }^{14} \mathrm{C}$ balance for this lake $\left(5 \mathrm{moles} / \mathrm{m}^{2} \mathrm{yr}\right)$ and the result based on the accumulation of bomb ${ }^{14} \mathrm{C}\left(38 \mathrm{moles} / \mathrm{m}^{2} \mathrm{yr}\right)$ is best explained by the steady-state introduction of carbon very low in ${ }^{14} \mathrm{C}$ from springs (Peng and Broecker, $\mathrm{ms}$ in preparation). As long as these springs do not carry significant amounts of bomb ${ }^{14} \mathrm{C}$, and as long as their ${ }^{12} \mathrm{C}$ budget has remained close to steady state, the bomb ${ }^{14} \mathrm{C}$ based estimate of $38 \mathrm{moles} / \mathrm{m}^{2} \mathrm{yr}$ should be valid.

For Pyramid and Walker Lakes, no significant discrepancy exists between the natural and bomb ${ }^{14} \mathrm{C}$ results. As the natural ${ }^{14} \mathrm{C}$ based values have high uncertainties, those based on bomb ${ }^{14} \mathrm{C}$ are used in the discussion which follows. The major uncertainty in these results stems from the lack of precise knowledge of the contribution of bomb ${ }^{14} \mathrm{C}$ to 
the lake via river inflow. Based on measurements of both ${ }^{14} \mathrm{C}$ and ${ }^{12} \mathrm{C}$ in the Truckee River (feeding Pyramid Lake) and the Walker River (feeding Walker Lake) (see fig 1 ), we estimate that $38 \pm 6$ percent of the excess ${ }^{14} \mathrm{C}$ in Pyramid Lake and $20 \pm 4$ percent of the excess ${ }^{14} \mathrm{C}$ in Walker Lake arrived via the rivers rather than via invasion of $\mathrm{CO}_{2}$ (Peng and Broecker, ms in preparation).

In the case of the Experimental Lakes Area in Canada, all the work has been done through the purposeful addition of tracers. In $1976,{ }^{226} \mathrm{Ra}$ and ${ }^{14} \mathrm{C}$ were added to the surface mixed layer of Lake 224 (25 hectares) and, in $1978,{ }^{226} \mathrm{Ra},{ }^{14} \mathrm{C}$ and ${ }^{3} \mathrm{H}$ were added to the surface mixed layer of Lake 226 ( $\sim 25$ hectares). By following the fate of ${ }^{14} \mathrm{C}$ added and by observing the ${ }^{222} \mathrm{Rn}$ to ${ }^{226} \mathrm{Ra}$ and the ${ }^{3} \mathrm{He}$ to ${ }^{3} \mathrm{H}$ ratio in the mixed layer, we have been able to calculate evasion rates for $\mathrm{CO}_{2}, \mathrm{Rn}$ and ${ }^{3} \mathrm{He}$. These results are summarized in table 1.

The conclusions to be drawn from these studies are as follows. The ELA lakes experience much lower gas exchange rates than the ocean. Gas exchange rates measured within $10 \mathrm{~m}$ diameter enclosures (with $\sim 20 \mathrm{~cm}$ high flotation collars) are the same or higher than those obtained for the lake as a whole. Thus, even though the flotation collar prevents surface waves from entering the enclosure, the gas exchange rate is not diminished.

Table 2 gives three characteristics (salinity, mean wind velocity, and $\mathrm{pH}$ ) that are likely to cause differing exchange rates from one system to the other. The $\mathrm{pH}$ is potentially important because the rate of conversion of $\mathrm{CO}_{2}$ to $\mathrm{HCO}_{3}-$ depends on the $\mathrm{OH}$ content of the
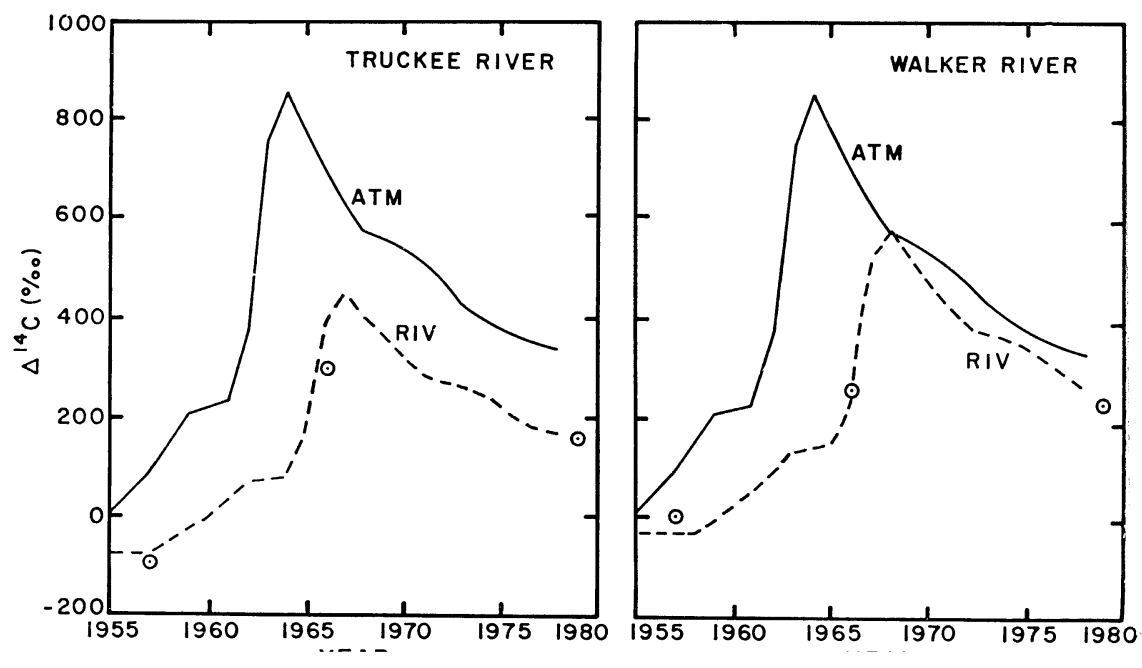


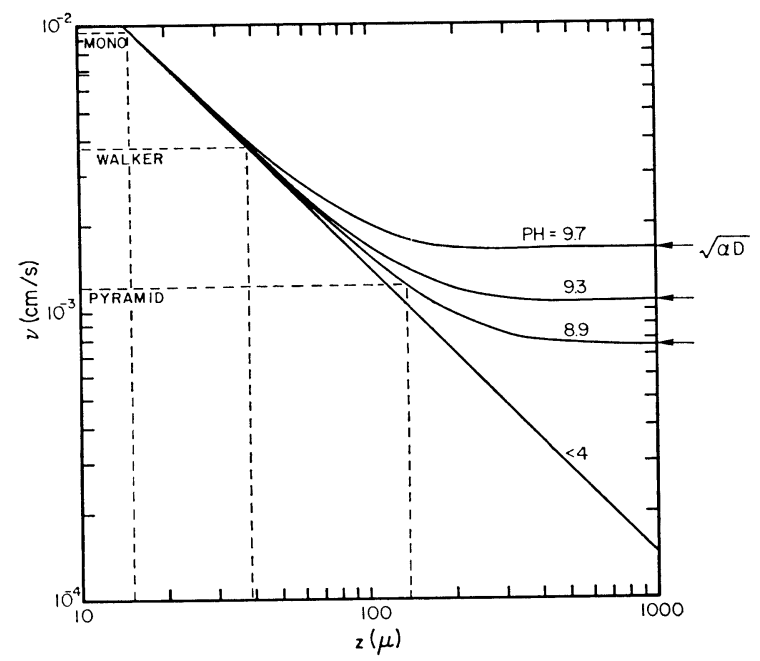

Fig 2. Piston velocity for $\mathrm{CO}_{2}$ as a function of stagnant film thickness for waters of various $\mathrm{pH}$ 's (all with $\mathrm{CO}_{2}$ partial pressures equal to the atmospheric value of $330 \times$ $10^{-}$atmospheres). The pH's chosen are those for the systems we have studied. The arrows show the value of $\sqrt{\alpha \mathrm{D}}$ for the $\mathrm{pH}$ shown (where $\alpha$ is the rate constant for the $\mathrm{CO}_{2}-\mathrm{HCO}_{3}$ - reaction and $\mathrm{D}$ is the $\mathrm{CO}_{2}$ molecular diffusivity).

solution. Thurber and Broecker (1972) have given curves showing the relationship between piston velocity and film thickness for waters of differing $\mathrm{pH}$ (but with $\mathrm{CO}_{2}$ partial pressures close to atmospheric). Figure 2 portrays this relationship. Except for Pyramid Lake, the influence of reaction enhancement of the $\mathrm{CO}_{2}$ invasion rate is quite small.

In figure 3, film thicknesses from table 1 are plotted against wind velocity. Also included are the month-long averages obtained off Barbados (Broecker and Peng, 1971), at station PAPA in the North Pacific (Peng, Takahashi, and Broecker, 1974), and for the Antarctic (Peng and others, 1979). For comparison, we give the wind tunnel curve obtained by the Hamburg group (Broecker, Peterman, and Siems, 1978). Assuming our results to be valid, some factor other than $\mathrm{pH}$ and wind velocity must be at work for Walker and Mono Lakes.

Table 2

Characteristics of the natural water bodies

$\begin{array}{cccc}\mathbf{T} & \mathrm{S} & \begin{array}{c}\text { Mean } \\ \text { wind vel }\end{array} & \mathrm{I}_{\mathrm{co}} \text {, }\end{array}$




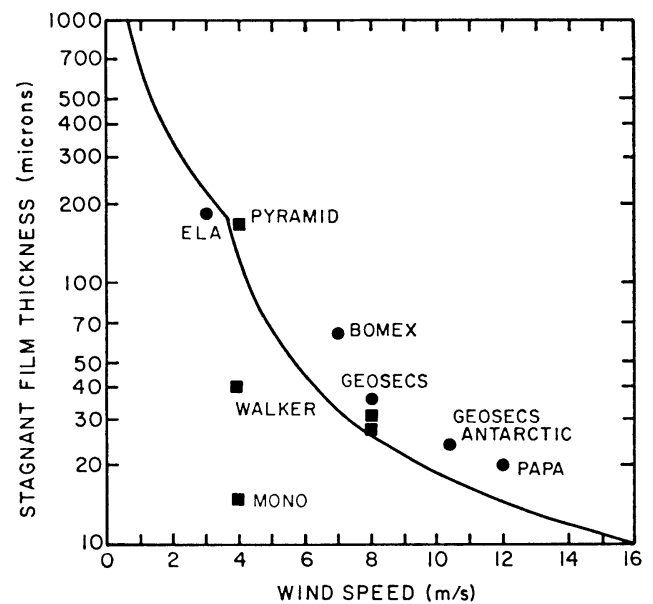

Fig 3. Film thickness versus wind velocity for the natural systems we have studied. The solid line is the curve obtained in the wind tunnel by the Hamburg group (Broecker, Peterman, and Siems, 1978) with the velocity translated to $10 \mathrm{~m}$ above surface (ie, 1.5 times the velocity measured at a height of $60 \mathrm{~cm}$ in the tunnel). The slope break in the wind tunnel curve corresponds to the initiation of capillary waves. 'The solid circles are estimated from radon method, and the squares are from radiocarbon method.

One possible explanation lies in the difference in salt content (and possibly in salt composition) among the systems studied. The salt content of Mono Lake is nearly twice that for the ocean. Is there any reason to believe that the characteristics of the viscous boundary layer are modified by the presence of ions?

In our radon extractions, we have long noted that sea water produces far finer bubbles than does fresh water. The photograph in plate 1 documents this difference. In order to explore this phenomenon, we have determined the extraction time for radon from waters of various $\mathrm{NaCl}$ contents. As can be seen in figure 4, a minimum in extraction time is found in the range of the salt content equivalent to that in sea water. Observation of the bubbles in these experiments reveals a decrease to $35 \mathrm{~g} / \mathrm{L}$ followed by a nearly constant value to $270 \mathrm{~g} / \mathrm{L}$. Thus, extraction time is not simply a function of bubble size. ${ }^{1}$

While the mechanics of the fluid at the interface of a plastic frit need not bear any relationship to those at the atmospheric interface, it is, indeed, possible that the phenomenon giving rise to small bubbles also gives rise to a thinner viscous layer. Our results are sufficiently convincing to indicate that the results obtained for fresh water in wind tunnels need not apply to sea water. Direct comparisons between sea water and fresh water must be conducted in a wind tunnel in order to demonstrate the role of salt in the gas exchange process. Both the influence of salt on

I For sea water, the bubbles are considerably smaller than those for the $35 \mathrm{~g} / \mathrm{L}$ $\mathrm{NaCl}$ solution. Mono Lake water yields bubbles indistinguishable from those for the $35 \mathrm{~g} / \mathrm{L} \mathrm{NaCl}$ solution (and also to those for the $270 \mathrm{~g} / \mathrm{L} \mathrm{NaCl}$ solution). 


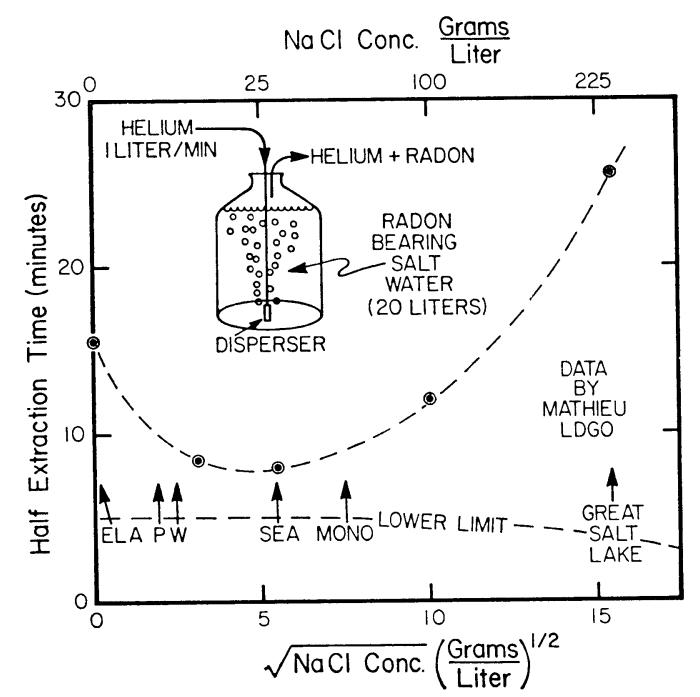

Fig 4. Half extraction time for radon as a function of salt content of the water. The lower limit curve is based on the assumption that the stripping gas becomes saturated with radon.

the wind velocity at which capillary waves are initiated and on the slope of the wind velocity/piston velocity relationship should be explored.

As bomb ${ }^{14} \mathrm{C}$ is such an important gas exchange tracer, the kinetics of the $\mathrm{CO}_{2}$ to $\mathrm{HCO}_{3}$ - reaction must be more carefully determined. Direct measurements on the waters of interest will have to be conducted.

Non-linearity in the relationship between gas exchange rate and wind velocity associated with the initiation of capillary waves requires that more thought be given to the method of averaging the conditions for water bodies experiencing low wind conditions. As the ELA lakes are often free of capillary waves (especially during the night), we should have some quantitative means of assessing the fraction of time that this condition exists.

\section{ACKNOWLEDGMENTS}

The ${ }^{3} \mathrm{He} /{ }^{4} \mathrm{He}$ data mentioned here were obtained by one of us (TT), using the facilities in the laboratory of William Jenkins at WHOI. The ELA experiments were possible only because of the excellent advice and help provided by David Schindler, who directs this facility. John Goddard documented the bubble-size relationship. Financial support came from National Science Foundation Grants OCE 78-20898, OCE 77-01430, OCE 75-15105, GB 36348, and GA 33124. Lamont-Doherty Geological Observatory contribution no. 2949. 


\section{REFERENCES}

Berger, Rainer, and Libby, W F, 1969, Equilibration of atmospheric carbon dioxide with sea water: possible enzymatic control of the rate: Science, v 164, p 1395-1397.

Bolin, B, 1960, On the exchange of carbon dioxide between the atmosphere and the sea: Tellus, v 12, p 274-281.

Broecker, H C, Peterman, J, and Siems, W, 1978, The influence of wind on $\mathrm{CO}_{2}$ exchange in a wind-wave tunnel, including the effects of monolayers: Jour Marine Research, v 36, p 595-610.

Broecker, W S and Walton, A, 1959, The geochemistry of C-14 in fresh-water systems: Geochim et Cosmochim Acta, v 16, p 15-38.

Broecker, W S and Peng, T-H, 1971, The vertical distribution of radon in the BOMEX area: Earth Planetary Sci Letters, v 11, p 99-108.

Emerson, S, Broecker, W S, and Schindler, D W, 1973, Gas exchange rates in a small lake as determined by the radon method: Research Board Canada Jour Fisheries, v 30, p 1475-1484.

Hesslein, R, Broecker, W S, Bower, P, and Quay, P, in press, Whole lake radiocarbon experiment: Research Board Canada Jour Fisheries, in press.

Lewis, W K, and Whitman, W C, 1924, Principles of gas absorption: Industrial Eng Chem, v 17, p 1215 .

Peng, T-H, Broecker, W S, Mathieu, G G, Li, T-H, and Bainbridge, A E, 1979, Radon evasion rates in the Atlantic and Pacific Oceans as determined during the GEOSECS Program: Jour Geophys Research, v 84, p 2471-2486.

Peng, T-H, Takahashi, T, and Broecker, W S, 1974, Surface radon measurements in the North Pacific Ocean station PAPA: Jour Geophys Research, v 79, p 1772-1780.

Thurber, D L and Broecker, W S, 1972, The behavior of radiocarbon in the surface waters of the Great Basin, in Olsson, I U, ed, Radiocarbon variations and absolute chronology, Nobel symposium, 12th: New York, John Wiley \& Sons, p 379-400. 